\title{
ОСОБЛИВОСТІ РЕПРЕЗЕНТАЦІЙ МАСКУЛІННИХ ОБРАЗІВ: ДИСКУРСИ СЧАСНИХ ТЕЛЕРЕКЛАМ (НА ПРИКЛАДІ УКРАЇНИ, РОСІЇ ТА ПОЛЬЩІ)
}

\section{О. Федоришин}

\author{
Львівський національний університет імені Івана Франка, \\ вул. Університетська, 1, м. Львів, Україна, 79000, \\ oks.apt95@gmail.com
}

\section{О. Козаченко}

\section{Львівський начіональний університет імені Івана Франка, вул. Університетська, 1, м. Львів, Україна, 79000, olyalviv3@gmail.com}

Стаття присвячена проблемі (від)творення маскулінних образів в сучасних телевізійних рекламних роликах. Медіа, зокрема реклама, з одного боку, може ставати джерелом недостовірної інформації та стереотипних уявлень, а з іншого - джерелом формування нових цінностей та норм поведінки. Мета дослідження - виявити основні дискурси сучасних телевізійних рекламних роликів України, Росії та Польщі в контексті (від)творення маскулінних образів. За допомогою контент-аналізу та дискурс-аналізу було проаналізовано рекламні ролики телебачення трьох країн України, Росії та Польщі. В результаті дослідження були виділені чотири дискурсивні способи репрезентації чоловіків: «Сім'янин», «Бізнесмен», «Звабник» та «Спортсмен», маскулінність яких вимірюється через такі «вузлові точки» як особливості зовнішнього вигляду, цінності, поведінка, емоції, середовище зображення та тематична спрямованість реклами. Узагальнення найвищих відсоткових значень усіх виділених та досліджуваних категорій дозволило виділити образ типового чоловічого образу. На українському телебаченні зображення чоловіка у рекламі пов' язані, зазвичай, з відпочинком, в одязі стилю «кежуал», зачіскою «бокс/напівбокс», атлетичної тілобудови, з вираженням соціальних цінностей та споживацькою поведінкою, виявом гедоністичних і комунікативних емоцій. У російській телерекламі образ чоловіка наступний: на відпочинку, одяг стилю «кежуал», зачіска спортивна, атлетичної тілобудови, 3 наданням переваги соціальним цінностям та демонстрацією споживацької поведінки, виявом гедоністичних і комунікативних емоцій. Для польського телебачення характерний образ: чоловік, зображення якого спостерігається в оточенні сім'ї, одяг стилю «кежуал», з зачіскою типу класичної чи британки, атлетичної тілобудови, з вираженням соціальних цінностей та комфортною поведінкою, виявом комунікативних $\mathrm{i}$ праксичних емоцій. За допомогою контент-аналізу реклами вдалось виявити, що на телебаченні усіх трьох країн найчастіше ми спостерігаємо образ «Сім’янина». Заува-

(C) Федоришин О., Козаченко О., 2017 
жимо, що український та російський телерекламні дискурси можемо охарактеризувати як традиційні, проте в Польщі спостерігаємо неоднозначність, а саме, боротьбу традиційного та ліберального дискурсу.

Ключові слова: гендер, маскулінність, мас-медіа, телереклама, дискурс.

Ми живемо в період, коли стрімкими темпами зазнають зміни взаємовідносини між чоловіками і жінками. Проте, гендерна дискримінація продовжує існувати в інформаційному просторі, набуваючи більш витончених і прихованих форм. 3 одного боку, масове репродукування у ЗМІ консервативних гендерних стереотипів (наприклад, постійне протиставлення жінок як чуттєвих, слабких до чоловіків як жорстких, сильних тощо) посилює традиційні уявлення про жінок і чоловіків, як докорінно різних осіб, з різними ролями та функціями у суспільстві. 3 іншого боку, ми спостерігаємо вкорінення «сучасних» уявлень про чоловічі та жіночі ролі, атрибути зовнішнього вигляду, розмиття кордонів між маскулінною та фемінною сферою діяльності (до прикладу, звернення уваги на важливість чоловічої зовнішності, претензія жінки на роль керівника у професійній сфері).

На сьогодні існує багато дослідників, які зосереджували свою увагу на різних аспектах такої суспільної проблеми як репрезентація чоловічих образів, зокрема у рекламному дискурсі. Основними дослідниками цієї проблеми слід вважати Т. Міллума, I. Гофмана, К. Шнайдера, С. Баріх-Шнайдера, О. Кікінеджі , Р. Барча, Т. Бурнетта, Т. Діллера тощо. До вітчизняних науковців, що працювали в цій сфері належать О. Кісь, Ю. Маслова, М. Кір'янова, Г. Свереда, Т. Бурейчак, М. Скорик, Л. Шевченко, Ю. Бєлікова, Л. Чернобай, О. Перелигіна та інші. Зауважимо, що гендерні відносини та медіапростір залишаються одними з найбільш динамічних сфер, які трансформуються у сучасному суспільстві, а тому попередні теоретичні напрацювання можуть виявитися не релевантними. Окрім того, недостатньо опрацьованим $є$ досвід порівняння українських та іноземних маскулінних рекламних дискурсів.

Мета дослідження - виявити основні дискурси сучасних телевізійних рекламних роликів України, Росії та Польщі в контексті (від)творення маскулінних образів. 3aвдання: виявити особливості дискурсивного вивчення мас-медіа, зокрема телереклами; розробити дослідницьку модель дискурсивних репрезентації маскулінних образів в телерекламі; дослідити способи представлення чоловічих образів в рекламних роликах (на українському, польському та російському телебаченні); здійснити порівняння результатів проведеного дослідження з іншими, суміжними по проблематиці.

У сучасних соціогуманітарних науках маскулінність $є$ одним із основних понять, яке означає «соціальні очікування від представників чоловічої статі і стосується соціально сформованих рис мужності (маскулінності)» [7]. Маскулінність можна визначити як певну систему нормативних уявлень про чоловіка, а саме про властивості таких його основних характеристик як зовнішність, манери поведінки, стиль життя, інтереси, цінності, установки, сексуальні орієнтації тощо. Рекламні простори можна розглядати як сферу, яка має сформований власний дискурс, виконує функції, наповнює змістом та надає значень певним суспільним практикам. У розгляді проблеми маскулінних стереотипних образів в телевізійних рекламних роликах ми вбачаємо 
доцільним використання теорії дискурсу Е. Лакло та Ш. Муффа. В такому разі чоловічий конструкт ми розглядаємо як дискурс, тобто як структуру взаємопов'язаних значень, які визначають концепт маскулінності та легітимізують приналежність до цієї гендерної групи. Саме значення, якими ми наділяємо образ чоловіка, визначають цілісність, комплексність сформованого образу, описують та наповнюють його певним змістом. Рекламну сферу (телевізійну рекламу) розглядаємо урізноманітненою багатьма дискурсами стосовно маскулінності, які впливають на наше світосприйняття, яке не буде статичним і змінюватиметься під впливом різноманіття рекламних повідомлень. Водночас, певні дискурси є гегемонними, через підтримку мас-медіа та укоріненість у масовій свідомості, стереотипах. Гегемонним гендерним дискурсом в українському суспільстві, на думку дослідниці Т. Бурейчак, являється патріархальний дискурс. Він утверджує чоловіка домінуючим в суспільстві, а тому емоційність, лагідність, надмірна увага до своєї зовнішності стають рисами непритаманними чоловікові [2, с. 9].

У авторському дослідженні нами була розроблена модель, в якій відображено найтиповіші характеристики чоловіків у сучасних рекламних роликах на телебаченні. Апробацію авторської моделі здійснюємо в емпіричному дослідженні за допомогою дискурс та контент-аналізу. Основна ідея дослідження полягає в крос-культурному порівнянні дискурсивних репрезентацій чоловічих образів в телерекламі на прикладі одних з найпопулярніших загальнонаціональних каналів України, Польщі та Росії. Ми припускаємо, що різний ступінь розвитку країн, культурне різноманіття, відмінні індивідуальні щоденні практики та розбіжністьціннісних орієнтацій можуть мати вплив на формування відмінних способів репрезентації маскулінності в медіа. Ми виділили чотири гіпотетичні дискурсивні способи репрезентації чоловіків, маскулінність яких можна виміряти через характерні «вузлові точкизтобто найвиразніші якості чоловічих образів, які ми можемо чітко спостерігати у рекламних роликах: 1. «Сім'янин». Припускаємо, що це чоловік в неофіційному стилі одягу, поведінка комфортна, батьківська, 3 проявом соціальних/духовних цінностей, праксичних, романтичних, гедоністичних емоцій. Такий образ зустрічаємо в рекламі побутових товарів, ліків, продуктів харчування та сфери послуг,відповідно відтворено середовище відпочинку, домівки, сімейного оточення або ж роботи. 2. «Бізнесмен». Маскулінний образ консервативного, ділового зовнішнього вигляду, поведінка споживацька, звернена на матеріальні цінності та комунікативні, глоричні, праксичні емоції. Такий образ зустрічаємо в рекламі алкогольних виробів, транспортних засобів, бізнесу та компаній, в робочому середовищі (трудовий колектив) або ж на відпочинку. 3. «Звабник». Неформальний привабливий зовнішній вигляд чоловіка, прояв естетичних цінностей, поведінка споживацька, репродуктивна; емоції глоричні, романтичні, естетичні. Чоловіка такого типу зображено в рекламі косметики, одягу, транспортних засобів, в середовищі розваг. 4. «Спортсмен». Припускаємо, що це образ чоловіка зі спортивним зовнішнім виглядом, агресивною поведінкою, з проявом економічних цінностей та глоричних, праксичних емоцій. Най частіше зустрічаємо в рекламі продуктів харчування, ліків, косметики, одягу; сфера

1 Вузлові точки (згідно дискурсивної теорії) - це привілейовані знаки, навколо яких упорядковуються та отримують своє значення інші знаки [11, с. 57]. 
зображення - заняття спортом, робота. Ми не можемо стверджувати, що будь-який 3 цих типів дискурсивної репрезентації маскулінності є завершеним і повним. Через незафіксованість елементів, інколи вони можуть бути мінливими і дещо відрізнятись від запропонованих у нашій моделі.

В основу соціологічного дослідження представлення чоловічих образів у рекламних роликах (на прикладі українського, польського та російського телебачення) покладено якісні візуальні методи отримання та обробки інформації емпіричних даних, а саме дискурс та контент-аналіз. Дослідження було проведено у період з 20 квітня 2016 року по 7 травня 2016 року у один з будніх днів (середа) та вихідний (субота), оскільки, припускаємо, що рекламний контент у обрані дні тижня може дещо різнитись. Для проведення дискурс та контент-аналізу було обрано перегляд реклам за участю чоловіків на українському каналі «ІНТЕР», на російському каналі «Россия 1» та польському каналі «TVP-1». Аналізу підлягали реклами, які транслювались у час з 18:30 до 22:00 (вечірній «прайм-тайм»). Дослідження проводилось згідно виділених критеріїв вибірки, тобто реклами без чоловічих образів не бралися до уваги. Спостереження відбувалось за унікальними рекламними роликами. Загальна кількість переглянутих унікальних рекламних роликів на каналі IHTEP - 35, Россия 1-34, TVP-1 - 34.

Отож, здійснивши контент-аналіз даних ми виявили такі відсоткові значення по основних спостережуваних категоріях (табл. 1).

Таблиия 1

Результати репрезентації чоловічих образів на телеканалах України, Росії та Польщі.

\begin{tabular}{|c|c|c|c|}
\hline & Україна (IНTЕР) & Росія (Россия-1) & Польща (TVP-1) \\
\hline $\begin{array}{l}\text { Зовнішній } \\
\text { вигляд: } \\
\text { Стиль одягу }\end{array}$ & $\begin{array}{l}\text { «Кежуал» }(43 \%), \\
\text { «Спортивний» }(20 \%), \\
\text { «Консервативний» та } \\
\text { «Елегантний» - (по } \\
11,5 \%) \\
\end{array}$ & $\begin{array}{l}\text { «Кежуал» }(44,1 \%), \\
\text { «Спортивний» та } \\
\text { «Консервативний» - } \\
\text { (по } 14,7 \%)\end{array}$ & $\begin{array}{l}\text { «Кежуал» }(41,2 \%), \\
\text { «Консервативний» } \\
(26,5 \%)\end{array}$ \\
\hline Зачіска & $\begin{array}{l}\text { «Бокс/напівбокс» }(28,6 \%), \\
\text { «Класична» }(23 \%)\end{array}$ & $\begin{array}{l}\text { «Бокс/напівбокс» } \\
(26,5 \%), \text { «Класична» та } \\
\text { «Боб»- }(20,6 \%)\end{array}$ & $\begin{array}{l}\text { «Класична», } \\
\text { «Британка»- } \\
(29,5 \%), \text { «окс/ } \\
\text { напівбокс» }(23,5 \%) \\
\end{array}$ \\
\hline Будова тіла & $\begin{array}{l}\text { Атлетична (мезоморфна) } \\
(68,5 \%)\end{array}$ & $\begin{array}{l}\text { Атлетична (мезоморфна) } \\
(53 \%)\end{array}$ & $\begin{array}{l}\text { Атлетична } \\
\text { (мезоморфна) } \\
(79,4 \%)\end{array}$ \\
\hline Цінності & $\begin{array}{l}\text { Соціальні (вітальні) } \\
(37,1 \%)\end{array}$ & $\begin{array}{l}\text { Соціальні (вітальні) } \\
(41,2 \%)\end{array}$ & $\begin{array}{l}\text { Соціальні (вітальні) } \\
(47 \%)\end{array}$ \\
\hline Поведінка & Споживацька $(51,4 \%)$ & Споживацька $(61,8 \%)$ & Комфортна (53\%) \\
\hline Емоції & Гедоністичні $(37,1 \%)$ & Гедоністичні (44,1\%) & $\begin{array}{l}\text { Комунікативні } \\
(41,2 \%)\end{array}$ \\
\hline \begin{tabular}{|l|} 
Середовище \\
зображення
\end{tabular} & Відпочинок $(31,4 \%)$ & Відпочинок $(29,4 \%)$ & $\begin{array}{l}\text { Сімейне оточення } \\
(35,3 \%)\end{array}$ \\
\hline $\begin{array}{l}\text { Тематична } \\
\text { спрямованість } \\
\text { реклами }\end{array}$ & $\begin{array}{l}\text { «Побутові товари» } \\
(28,6 \%)\end{array}$ & $\begin{array}{l}\text { «Продукти харчування» } \\
(35,3 \%)\end{array}$ & «Ліки» $(26,5 \%)$ \\
\hline
\end{tabular}


Звертаючи наш погляд на відсоткове значення показників, що мають найвище значення в рамках кожної з країн по окремості, можемо змоделювати певні образи, які уособлюють найхарактерніший візуальний маскулінний тип. Тому, візуалізація середньостатистичного чоловічого образу, який ми частіше за все можемо спостерігати в телерекламі виглядатиме наступним чином. На украӥнському телебаченні: зображення чоловіка на відпочинку в одязі стилю «кежуал», зачіскою «бокс/напівбокс», атлетичної тілобудови, з вираженням соціальних цінностей та споживацькою поведінкою, виявом гедоністичних і комунікативних емоцій. На російському телебаченні: образ чоловіка на відпочинку, одяг стилю «кежуал», зачіска спортивна, атлетичної тілобудови, з наданням переваги соціальним цінностям та демонстрацією споживацької поведінки, виявом гедоністичних і комунікативних емоцій. На польському телебаченні: чоловік, зображення якого спостерігається в оточенні сім’і, одяг стилю «кежуал», з зачіскою типу класичної чи британки, атлетичної тілобудови, з вираженням соціальних цінностей та комфортною поведінкою, виявом комунікативних і праксичних емоцій. Таким чином, аналіз демонструє схожість рекламних маскулінних образів на українському та російському телебаченні фактично за усіма характеристиками (окрім тематичної спрямованості реклами). Натомість на польському телебаченні спостерігаємо відмінний образ за показниками зачіски, поведінки, емоцій, середовища зображення та тематичної спрямованості реклами.

Згідно результатів дослідження на українському телебаченні в аналізованих роликах образ «Сім'янин» зустрічався у 40 \% спостережуваного контенту, «Бізнесмен» - 28,5 \%, «Звабник»- 8,6 \%, «Спортсмен» - 5,7 \% і 17,1 \% реклам не підпадали під жодну виокремлену категорію. Згідно результатів дослідження російських рекламних повідомлень (як і на українському телебаченні), найбільш розповсюдженими є образи «Сім'янина» $(44,1 \%)$ та «Бізнесмена» $(35,3$ \%), «Звабника» і «Спортсмена» рідше (по 5,9 \%,) і 8,8 \% реклам не підлягали ототожненню з жодною категорією. У польській телерекламі образ «Сім'янина» займає 53 \% контенту, «Бізнесмена» та «Звабника» по 14,7\%, «Спортсмена - 11,7 \% і лише 5,8 \% рекламних роликів не співставлено з жодною категорією.

Зауважимо, що у трьох країнах яскраво вимальовується традиційний дискурс у сфері зображення маскулінного образу, як гегемонний, та ліберальний дискурс, як маргіналізований. Як ми і припускали, українське та російське телебачення в своїх рекламних повідомленнях має домінуюче відтворення таких образів чоловіка як «Сім'янин» та «Бізнесмен», які уособлюють характеристики патріархального укладу цих суспільств. Зображення такого типу маскулінного образу відтворюються у рекламах побутових товарів, продуктів харчування, ліків, бізнесу і компаній, сфери послуг, авто тощо. У той же час, образи «Звабника» і «Спортсмена» в рекламах на телебаченні України та Росії ми спостерігаємо порівняно мало, адже це стереотипізовані уявлення про чоловіка, який є виразником категорій мачізму (яскраве вираження сексуальності, демонстрація чоловічої сили, домінуючої позиції в суспільстві, завойовницька поведінка по відношенню до жінки) та фейсизму (тіло та зовнішність - важливий атрибут чоловіка, що дає змогу зваблювати жінок, тому догляд за ним $є$ одним з основних аспектів діяльності чоловіка). Зазвичай, такий образ ми спостерігаємо в рекламах алкогольних виробів, авто, косметики та одягу для чоловіків. 
Аналізуючи результати дослідження стосовно польського телевізійного дискурсу, відзначаємо його неоднозначність. Ми спостерігаємо, що гегемонну позицію серед рекламних повідомлень тут займає образ «Сім’янина», який є традиційним, а його характеристики більш консервативними. Маргіналізованими є усі інші образи «Бізнесмена», «Звабника» $\mathrm{i}$ «Спортсмена», проте, з майже однаковою відсотковою значимістю, за результатами нашого дослідження. Можна припустити, що це спричинено лібералізацією та узагальненою зміною вузьких поглядів на чоловічі практики у повсякденному житті, які не стосуються забезпечення та підтримки матеріального становища сім’ї, іiі захисту тощо, а враховують право на урізноманітнене дозвілля, практики догляду за зовнішністю. 3 огляду на це, ми висуваємо припущення, що в межах польського телебачення немає чіткого однозначного визначення образу чоловіка, адже спостерігаємо боротьбу двох, певною мірою рівнозначних, дискурсів, які заявляють про свої канони зображення маскулінного образу як домінуючого. 3 одного боку, традиційний дискурс дає нам означення чоловіка згідно виокремлених нами типів «Сім’янин» (тут: як такого, що домінує над усіма іншими) та «Бізнесмен», а ліберальний дискурс утверджує трансформований, осучаснений погляд на маскулінність, що вбачається у візуалізації «Звабника» і «Спортсмена» (такі, які за показниками наближені до традиційного образу «Бізнесмен»). Отож, підсумовуючи, маємо змогу зазначити, що попри існування традиційності у зображенні чоловічих образів, бачимо новий підхід до зображення чоловічого образу в межах рекламного дискурсу на польському телебаченні.

Варто зазначити, що у нашому дослідженні вивчено і змальовано не всі гендерні стереотипи, які можуть використовуватись рекламою, але найбільш уживані. Отож, установки маскулінності розприділяються у рекламі таким чином, що чоловік $є$ домінантним як на фізичному, так і на інтелектуальному рівні, а його основний обов 'язок - насолоджуватись красою жінки та допомагати їй. Але, на сьогоднішній день ми все більше спостерігаємо приклади розмиття вузьких рамок вищезазначених стереотипів. При аналізі телевізійного контенту України, Польщі та Росії саме образ «Сім'янина» 3 проявом соціальних, духовних та естетичних цінностей, комфортної та батьківської поведінки зображується в більшості в середовищі відпочинку з сім'єю, вдома чи на роботі. Такий тип дискурсивної репрезентації чоловіків трапляється у 40 \% українського контенту, 53 \% польського та 44,12 \% російського. Відбувається руйнація стереотипних рамок творення образу чоловіка як затятого бізнесмена або ж хтивого мачо.

Для кращої ілюстрації зображуваних чоловічих образів наведемо декілька прикладів відповідних рекламних повідомлень. Приклад (від)творення образуСім'янина» спостерігаємо в рекламі вітамінів для усієї сім’ї «Суперія (Superia)». Тут виразно спостерігаємо знаки «вузлових точок» дискурсу - невибагливий, буденний одяг стилю кежуал, зачіска «британка» та астенічна (підтягнута) будова тіла, цінності - соціальні, що проявляються у життєрадісному перебуванню в колі близьких, привертання уваги до особистого здоров'я та рідних, батьківська поведінка (опіка над дітьми в спокійній атмосфері), романтичні, гедоністичні емоції (задоволення потреби в душевному комфорті перебування серед рідних, насолода приємними почуттями безтурботності), середовище зображення - на відпочинку у колі сім'і. 
Яскравий зразок в рекламному дискурсі такого маскулінного образу як «Бізнесмен» бачимо в рекламі банку ВТБ (VTB Bank). У ній спостерігаємо образ серйозного ділового чоловіка, який підкріплюється зовнішніми атрибутами: консервативний стриманий одяг (офіційний костюм), зачіска «бокс», астенічна (статна) будова тіла, цінності - матеріальні (в рекламі - фінансова вигода, прибуток від користування банківськими послугами), споживацька поведінка (мета головного героя спонукати споживача до активної дії в напрямку співпраці з компанією, що підкріплюється наведенням прикладу особистого користування вигідними послугами; з цією ціллю у настрої чоловіка спостерігаємо серйозність, переконливу манеру мовлення), комунікативні, глоричні емоції (бажання поділитись вдалим досвідом споживання банківських послуг, самоствердження і почуття гордості за себе, переваги над іншими). Щодо самого рекламного ролику, варто зауважити, що саме середовище, в яке поміщений чоловік - нейтральне, він сидить у пустому приміщенні у офісному кріслі, проте, позаду замість стіни розміщений фон, на якому транслюються уривчасті ролики з життя бізнес-компанії - ділові зустрічі, велика кількість робітників, які займаються виконанням своїх обов'язків, монети, які падають нізвідки тощо).

Прикладом образу «Звабник» може слугувати реклама засобу по догляду за шкірою для чоловіків (лосьйон до та після бриття) «NIVEA MEN». Чоловік зображується у ванній кімнаті (середовище зображення - дім, зачіска - «британка»), оголений торс - важлива ознака, яка демонструє нам прояви мачізму (атлетична будова), його увага звернена на особистий зовнішній вигляд, його привабливість (естетичні цінності), тому чоловік скрупульозно підходить до справи - спочатку проводить «ритуал» гоління, останнім кроком є зволоження шкіри. В ролику робиться візуальний акцент на продуктах, які дають змогу виглядати справжньому чоловікові на всі 100\%, адже наприкінці рекламного повідомлення з'являється жінка, яка з захопленням споглядає за чоловіком, він при цьому відчуває гордість, задоволення, самоствердження (поведінка - споживацька, емоції - глоричні, романтичні, естетичні).

Щодо образу «Спортсмена», то його ідентифікуємо в рекламному ролику чіпсів «Lays (Лейс)». Головний герой - відомий на весь світ футболіст, перебуває одночасно у різних локаціях - на стадіоні, маневруючи футбольним м'ячем та вдома, в оточенні друзів. Відповідно зовнішній вигляд його змінюється від спортивної тренувальної форми до буденного «кежуал» одягу, зачіска «боб», i, звичайно ж, атлетична тілобудова. Проте, це лише другий план, адже головну увагу звертає на себе упаковка «Lays», яка весь час у руках спортсмена, ніщо його не може відволікти і перервати насолоду від споживання продукту. Таким чином , спостерігаємо естетичні та матеріалістичні цінності (як надання переваги насолоді матеріальним), споживацька поведінка, емоції праксичні, пугнічні (приємне задоволення від виконуваних дій).

Порівняємо результати нашого дослідження з результатами, які були отримані іншими соціологами. Олена Рудковська (Київський національний університет імені Тараса Шевченка) у своїй роботі «Гендерні стереотипи у рекламі» (українське телебачення, 2014 рік) виділяє такі стійкі стереотипні образи як «чоловік-мачо», «чоловікексперт», «чоловік-успішний», «чоловік-мандрівник», «чоловік-жертва» [8]. Образ «чоловіка-мачо» та «чоловіка-мандрівника», на нашу думку, в цьому контексті дещо 
перегукуються. Перший описує маскулінний стереотип наповнений мужністю, незалежністю й демонстративною силою, він завжди впевнений у собі та випромінює сексуальність. Не дарма, авторка звертається до атрибутів мачізму, які перелічує Оксана Кісь - це фізична сила, сміливість, агресивність [8]. Другий тип описує невтомного героя, який здатен підкорити будь-які вершини, вижити за будь-яких умов. 3 цими образами, а саме описом їх яскравих характеристик корелює виокремлений нами образ «Звабника». Образи «чоловік-експерт» та «чоловік-успішний» дослідниця описує як професіонала. Саме тому у рекламах часто використовують відомих знаменитостей, застосовуючи аналогію між їхнім особистим успіхом та тим, що ви можете отримати це все скориставшись продуктом реклами. Схожі $є$ описи стереотипного образу у нашій виокремленій типології - образ «Бізнесмен».

У ще одній роботі «Візуальний образ чоловіка в рекламному дискурсі України як репрезентаційна модель маскулінності» Шкабари Маргарити (2015 р.). Дослідниця зазначає, що рекламним дискурсом активно використовуються прийоми мачізму та фейсизму, які формуються за допомогою звернення уваги на фізичних характеристиках, матеріальному становищі. Припущення підкріплюються емпіричним матеріалом, на основі якого виокремлено такі маскулінні образи: «Кар'єрист-спеціаліст» (зображення чоловіка-керівника, його мета - успішна бізнесова діяльність, кар'єрний ріст); «Супермен» (безстрашний та мужній, долає будь-які перешкоди); «Звабник» (головна мета - завоювати жінку, яскраво демонструє свою привабливість); «Політик» (лідер, управлінські навики, патріотизм, розум, розсудливість, рішучість тощо) [10]. Проводячи порівняння з нашим дослідженням бачимо, що за якісними характеристиками образ «Кар 'єриста-спеціаліста» та «Політика» відповідає нашому образу «Бізнесмена» як зразку професіоналізму, що демонструє свою першість, професіоналізм, інтелектуальні здібності та важливість, «Супермен»- «Спортсмену», де акцентується увага на фізичній силі чоловіка, його всесильності, здатності до боротьби та активності, а також цілковите співпадіння образів, які накладаються не тільки описом однакових рис характеру, але й назвами - «Звабник» - це чоловік з яскравою демонстрацією своєї сексуальності, фізичної привабливості, рішучості в плані завоювання жінки.

Підводячи підсумки, можемо зауважити, що виділені нами образи дискурсивних репрезентацій маскулінних образів у рекламних дискурсах мають виражену схожість 3 тими, які виділяють інші дослідники. Це підтверджує той факт, що наша розвідка була вдалою і відтворила наближену картину українських, польських та російських традицій у репродукуванні чоловіка як гендерної ідентичності в полі телебачення.

Отож, розглядаючи маскулінність з точки зору дискурс-аналітичного підходу, цей термін позначає певну реальність, з певними наявними характеристиками, які лише у співвідношенні, взаємодії і відтворюваності у певній сфері набувають визначеності. Нашим завданням було розглянути конструкт маскулінності в контексті репрезентації чоловічого образу в рамках рекламного дискурсу на телебаченні. Реклама як дискурс репрезентує нам різні моделі дискурсивного представлення образу чоловіка - від традиційних до модерних. В результаті дослідження були виділені чотири дискурсивні способи репрезентації чоловіків - «Сім’янин», «Бізнесмен», «Звабник» та «Спортсмен», маскулінність яких вимірюється через такі «вузлові точки» як особливості 
зовнішнього вигляду, цінності, поведінка, емоції, середовище зображення та тематична спрямованість реклами. Існує боротьба різних дискурсів за визначення образу чоловіка. Саме телебачення є зразком плюралізму дискурсів в контексті (від)творення чоловічого образу. Репрезентації чоловічих образів в межах українського і російського телебачення різняться своїм наповненням від польського контенту. Проте все ж, образ «Сім'янина» $\epsilon$ домінуючих на телебаченні у всіх трьох країнах. Розглядаючи результати дослідження також зазначимо, що український та російський дискурси можемо охарактеризувати як традиційні, проте в телерекламах Польщі спостерігаємо неоднозначність, а саме боротьбу - традиційного та ліберального дискурсу.

\section{СПИСОК ВИКОРИСТАНОЇ ЛІТЕРАТУРИ}

1. Бурейчак T. Соціологія маскулінності : навчальний посібник / Тетяна Бурейчак. Львів : «Магнолія 2006», 2011. - 142 с.

2. Бурейчак T. С. Конструювання гендерних ідентичностей в дискурсах реклами. Автореферат / Т. С. Бурейчак. - Київ, 2007. - 18 с.

3. Бурейчак T. С. Рекламні стратегії конструювання нормативних гендерних дискурсів / Бурейчак Т. С. // Вісник Львів. Ун-ту. Сер. соціол. - 2008. - Вип. 2. - 240 с.

4. Васьківський Ю. Гендерний аспект телевізійної реклами: український та зарубіжний досвід / Васьківський Ю., Кіца М. Теле- та радіожурналістика. - Вип. 10. - 2011. C. 56-63.

5. Гендерні студії в сучасній Україні : матеріали студ. наук.-практ. конф. (12-13 березня 2015 р.) : зб. наук. ст. / [гол. ред. С. О. Філоненко]. - Бердянськ : БДПУ, 2015. - 96 с.

6. Гендерні ресурси українських мас-медіа: ціна і якість. Практичний посібник для журналістів та працівників ЗМІ / Н. М. Сидоренко, М. М. Скорик. - Київ : К.І.С., 2004. - $76 \mathrm{c}$.

7. Маскулінність [Електронний ресурс] // Словник гендерних термінів. - Режим доступу: http://a-z-gender.net/ua/maskulinnist.html

8. Рудковська О. Гендерні стереотипи у рекламі [Електронний ресурс] / Рудковська О. // Наукові дослідження українського медійного контенту: соціальний вимір - Режим доступу: http://www.journ.univ.kiev.ua/ndumk/index.php/component/content/article/92-2/ kontent-ukrainskoi-reklamy-ta-zv-iazkiv-z-hromadskistiu/103-henderni-stereotypy-ureklami

9. Фемінність та маскулінність [Електронний ресурс] // Часопис «ї». - №27. - 2003. Режим доступу: http://www.ji.lviv.ua/n27texts/N27-fem.htm

10. Шкабара М. Візуальний образ чоловіка в рекламному дискурсі України як репрезентаційн модель маскулінності [Електронний ресурс] / Шкабара М // Науковий блог НаУ «Острозька академія». - Режим доступу: http://naub.oa.edu.ua/2015/\%D0\%B2\%D1\%96 $\% \mathrm{D} 0 \% \mathrm{~B} 7 \% \mathrm{D} 1 \% 83 \% \mathrm{D} 0 \% \mathrm{~B} 0 \% \mathrm{D} 0 \% \mathrm{BB} \% \mathrm{D} 1 \% 8 \mathrm{C} \% \mathrm{D} 0 \% \mathrm{BD} \% \mathrm{D} 0 \% \mathrm{~B} 8 \% \mathrm{D} 0 \% \mathrm{~B} 9-$ $\%$ D0\%BE\%D0\%B1\%D1\%80\%D0\%B0\%D0\%B7-\%D1\%87\%D0\%BE\%D0\%BB\%D0\%B E\%D0\%B2\%D1\%96\%D0\%BA\%D0\%B0-\%D0\%B2-\%D1\%80\%D0\%B5\%D0\%BA\%D0 $\% \mathrm{BB} \% \mathrm{D} 0 \% \mathrm{~B} 0 \% \mathrm{D} 0 \% \mathrm{BC} \% \mathrm{D} 0 \% \mathrm{BD} \% \mathrm{D} 0 \% \mathrm{BE} /$

11. Йоргенсен М. В. Дискурс-анализ. Теория и метод. / М. В. Йоргенсен, Л. Дж. Филлипс. - Харків: Изд-во «Гуманитарный Центр», 2008. - 352 с. 


\section{REFERENCES}

1. Bureichak T. Sotsiolohiia maskulinnosti : navchalnyi posibnyk[Sociology of masculinity: a textbook] / Tetiana Bureichak. - Lviv : «Mahnoliia 2006», 2011. - $142 \mathrm{~s}$.

2. Bureichak T. S. Konstruiuvannia hendernykh identychnostei $\mathrm{v}$ dyskursakh reklamy. Avtoreferat [The construction of gender identities in the discourse of advertising] / T. S. Bureichak. - Kyiv, 2007. -18 s.

3. Bureichak T.S. Reklamni stratehii konstruiuvannia normatyvnykh gendernykh dyskursiv [Advertising strategy of constructing normative gender discourses] / Bureichak T. S. // Visnyk Lviv. Un-tu. Ser. cotsiol. - 2008. - Vyp. 2. - 240 s.

4. Vaskivskyi Yu. Hendernyi aspekt televiziinoi reklamy: ukrainskyi ta zarubizhnyi dosvid [The gender aspect of television advertising: Ukrainian and international experience] / Vaskivskyi Yu., Kitsa M. Tele- ta radiozhurnalistyka. - Vyp. 10. - 2011. - S. 56-63.

5. Henderni studii v suchasnii Ukraini : materialy stud. nauk.-prakt. konf. (12-13 bereznia 2015 r.) [Gender studies in contemporary Ukraine: research and practice conference proceedings (12-13 of march 2015 year)]: zb. nauk. st. / [hol. red. S. O. Filonenko]. - Berdiansk : BDPU, 2015. - $96 \mathrm{~s}$.

6. Genderni resursy ukrainskykh mas-media: tsina i yakist. Praktychnyi posibnyk dlia zhurnalistiv ta pratsivnykiv ZMI [Gender resources of Ukrainian mass media: price and quality. A practical guide for journalists and media employees]/ N. M. Sydorenko, M. M. Skoryk. - K.: K.I.S., 2004. - 76 s.

7. Maskulinnist [Elektronnyi resurs] // Slovnyk gendernykh terminiv [Glossary of gender terms]. - Rezhym dostupu: http://a-z-gender.net/ua/maskulinnist.html

8. Rudkovska O. Henderni stereotypy u reklami [Elektronnyi resurs] [Gender stereotypes in advertising. Scientifi c studies of Ukrainian media content: the social dimension]/ Rudkovska O. // Naukovi doslidzhennia ukrainskoho mediinoho kontentu: sotsialnyi vymir - Rezhym dostupu: http://www.journ.univ.kiev.ua/ndumk/index.php/component/content/article/92-2/ kontent-ukrainskoi-reklamy-ta-zv-iazkiv-z-hromadskistiu/103-henderni-stereotypy-ureklami

9. Feminnist ta maskulinnist [Elektronnyi resurs] // Chasopys «Yi» [Journal „Ï»]. - \#27. 2003. - Rezhym dostupu: http:/www.ji.lviv.ua/n27texts/N27-fem.htm

10. Shkabara M. Vizualnyi obraz cholovika v reklamnomu dyskursi Ukrainy yak reprezentatsiina model maskulinnosti [Elektronnyi resurs] [A visual image of a man in advertising discourse of Ukraine as a representative model of masculinity] / Shkabara M // Naukovyi blog NaU «Ostrozka akademiia». - Rezhym dostupu: http://naub.oa.edu.ua/2015/\%D0\%B2\%D1 $\% 96 \% \mathrm{D} 0 \% \mathrm{~B} 7 \% \mathrm{D} 1 \% 83 \% \mathrm{D} 0 \% \mathrm{~B} 0 \% \mathrm{D} 0 \% \mathrm{BB} \% \mathrm{D} 1 \% 8 \mathrm{C} \% \mathrm{D} 0 \% \mathrm{BD} \% \mathrm{D} 0 \% \mathrm{~B} 8 \% \mathrm{D} 0 \% \mathrm{~B} 9-$ $\% \mathrm{D} 0 \% \mathrm{BE} \% \mathrm{D} 0 \% \mathrm{~B} 1 \% \mathrm{D} 1 \% 80 \% \mathrm{D} 0 \% \mathrm{~B} 0 \% \mathrm{D} 0 \% \mathrm{~B} 7-\% \mathrm{D} 1 \% 87 \% \mathrm{D} 0 \% \mathrm{BE} \% \mathrm{D} 0 \% \mathrm{BB} \% \mathrm{D} 0 \% \mathrm{~B}$ E\%D0\%B2\%D1\%96\%D0\%BA\%D0\%B0-\%D0\%B2-\%D1\%80\%D0\%B5\%D0\%BA\%D0 $\% \mathrm{BB} \% \mathrm{D} 0 \% \mathrm{~B} 0 \% \mathrm{D} 0 \% \mathrm{BC} \% \mathrm{D} 0 \% \mathrm{BD} \% \mathrm{D} 0 \% \mathrm{BE} /$

11. Iorgensen M.V. Diskurs-analiz. Teoriia i metod [Discourse analysis. Theory and method]. / Iorgensen M.V., Fillips L. Dzh. - Kh.: Izd-vo «Gumanitarnyi Tsentr», 2008. - 352 s. 


\title{
SPECIAL ASPECTS OF REPRESENTATIONS OF MASCULINE IMAGES: THE DISCOURSES OF MODERN TELEVISION ADVERTISING (THROUGH THE EXAMPLE OF UKRAINE, RUSSIA AND POLAND)
}

\section{O. Fedoryshyn}

\author{
Ivan Franko National University of Lviv, \\ Universytetska Str., 1, Lviv, 79000, Ukraine \\ oks.apt95@gmail.com
}

\section{O. Kozachenko}

\author{
Ivan Franko National University of Lviv, \\ Universytetska Str., 1, Lviv, 79000, Ukraine \\ olyalviv3@gmail.com
}

This article is concerned with the problem of masculine image creation in modern television commercials. Media, particularly advertising, on the one hand, may become a source of misinformation and stereotyped images, and on the other - the source of formation of new values and behaviors. Research objective is to reveal the main discourses of modern television commercials in Ukraine, Russia and Poland in the context of masculine image creation. Goals: to identify the special aspects of a discursive study of mass media, in particular television advertising; to develop research model of the discursive representation of masculine images in television advertising; to explore ways of presenting the male images in the commercials (in Ukrainian, Polish and Russian television); to compare the results of the research with the others similar.

Masculinity can be defi ned as a system of normative conceptions of man, namely the properties of such basic characteristics as appearance, behavior pattern, life style, interests, values, attitudes, sexual orientation, etc. These and other categories involve compliance with their own psychological gender, the adoption of sex-role stereotypes. Advertising spaces can be considered as a sphere, which has its own discourses, put on an idea and provide values to certain social practices.

TV commercials of three countries - Ukraine, Russia and Poland - were analyzed through the use of content analysis and discourse analysis. As a result of the study, four discursive methods of male representation were identifi ed: «Family man», «Businessman», «Seducer», and «Sportsman», masculinity of which is measured through such «nodal points» as features of appearance, values, behavior, emotions, image environment and thematic scope of advertising. There is a competition between different discourses for defi ning the image of a man. The television is an example of the discourses plurality in the context of masculine image creation. With the help of content analysis, we managed to discover that we often watch on a television of all three countries the image of «Family man». The generalization of the highest percentages of all detailed and covered categories allowed us to highlight a typical 
male image. On the Ukrainian television, the image of a man in advertising is associated, usually, with rest, casual style, crew cut, athletic build, with expression of social values and consumer behavior, hedonistic and communicative emotions. In the Russian TV advertising the image of a man is as follows: on vacation, casual style, sport hairstyle, athletic build, giving preference to social values and a demonstration of consumer behavior, expression of hedonistic and communicative emotions. For Polish television, the typical image is: a man surrounded by a family, casual style, with classical hair style, athletic build, with an expression of social values and comfort behavior, communicative and practical emotions. Based on the results of our study, we note that Ukrainian and Russian TV advertising discourses can be characterized as traditional, but in Poland we observe ambiguousness, namely the confl ict between traditional and liberal discourse.

Key words: gender, masculinity, mass media, television advertising, discourse. 